\title{
島根県・山口県の茶粥習俗
}

早川史子* · 岡崎章子* · 猪口智子* · 韓 順子**

（*滋賀県立大学人間文化学部，**東海学園大学人間健康学部)

\section{Custom of rice porridge in green tea and its distribution in Shimane and Yamaguchi prefectures}

\author{
Fumiko Hayakawa*, Akiko Okazaki*, Tomoko Inokuchi*, Soon-ja Han** \\ *University Shiga Prefecture, 2500, Hassaka-cho, Hikone-shi, Shiga, 522-8533 \\ **Tokai Gakuen University, Faculty of Human Wellness, 2-901, Nakahira, Tenpaku-ku, \\ Nagoya-shi, 468-8514 \\ *厂522-8533 滋賀県彦根市八坂町 2500 \\ **\%468-8514 愛知県名古屋市天白区中平 2-901
}

\begin{abstract}
A questionnaire survey on the manners and the custom of rice porridge with green tea was conducted an object of inhabitants aged 50 or older on in Shimane and Yamaguchi Prefectures from 2003 to 2004 .

The following were found:

(1) In habitants, $60 \%$ and $83 \%$ of of the population in Shimane and Yamaguchi prefectures, respectively, who have experiences to eat rice porridge with green tea. The manners and customs of eating rice porridge with green tea has been widespread in both prefectures.

(2) A common name for rice porridge with green tea was "Chagai" or "Chagayu" whose frequency of use was the highest in both prefectures.

(3) Rice porridge with green tea was had for breakfast in both prefectures. Sweet potatoes were very popular ingredients in rice porridge with green tea, and then glutinous rice cake and broad beans were sometimes used..

(4) Rice porridge with green tea has been recognized as a meal to save rice, or to be good for health, and it has been inherited as a cuisine that meets preference in both prefectures.
\end{abstract}

Our questionnaire survey reveals that there are the manners and the custom of rice porridge with green tea common to Shimane and Yamaguchi prefectures. These results suggest that the manners and custom of rice porridge with green tea in both prefectures has been inherited since the Edo period.

\section{1. 緒言}

茶粥に関する論文1) 3)では，1600年代に，京都，大阪， 堺あたりの町家で年中茶粥が朝食べられていたことや 1800年代に，次第に村人が町家を真似て，茶粥を食べは じめるようになったことを推測している。また，大正時 代の主食調査 ${ }^{4)}$ や昭和初期の食事調査の結果5) 15) から,
当時茶粥習俗が西日本に広く分布していたことがわかる。 しかし，これらの文献はいずれも組織的に検討されたも のではなく，それぞれの調査は狭い地域に限定されてい る。広範囲に茶粥習俗を明らかにするためにはその全体 像の把握と詳細な調査・検討の組み合わせが必要である。 著者ら $\left.\left.{ }^{3)}, 16\right), 17\right)$ は茶粥習俗を総合的にとらえ, 長く食 べられてきた日本の食文化のひとつである茶粥を通して， 
食文化の成立，伝播，定着，衰退の過程とそれらの要因 を明らかにするために, 近畿地方（和歌山県·奈良県· 大阪府·京都府·滋賀県), 三重県，佐賀県に抢汀茶 粥習俗の内容と分布状況を調べた。佐賀県における茶粥 の習慣は1640年頃，鍋島藩の財政が窮乏したために藩が 質素倹約の命を下し民衆が半ば強制的に食べさせられて きた地域や水田に適さない地域でみられることが明らか になった ${ }^{17)}$ 。著者らの結果 $\left.\left.{ }^{3)}, 16\right), 17\right)$ から茶粥に関する内 容にはそれぞれの地域間で関連性があることが明らかと なった。

これまで著者らが調べた調查地以外にも茶粥習俗は分 布して抢り，中でも島根県と山口県は広範囲に分布して いる地域である5),6)。明治時代から大正時代にかけて島 根県の大田市や浜田市では商家や医師宅, コメからの収 入が得られた農家などでは貧富の差もなく茶粥が食べら れていたが，地主の家では食べられていなかった ${ }^{18), 19) 。 ~}$ また，石見地方全域では明治末期まで上流者は団子もち， 中下流者はサツマイモを入れた茶粥を食べていた ${ }^{20)} 。 一$ 方, 山口県では米麦の節約のために, 1600年代初頭から 朝食に茶粥を食べる習慣があり21)，いかなる人も茶粥で 育ってきた22) とされている。岩国の茶粥は「岩国茶粥」 「大島茶粥」と呼ばれており, 茶粥の始まりには次のよ うな説がある。ひとつは毛利氏一族の吉川広家（15611625年）が関が原の戦い（1600年）の後に岩国に移封さ れ, 幕府から領地が減らされたことになり，米の収穫量 が減少したことから吉川広家は家臣にコメを節約させる 目的で茶粥を勧めた ${ }^{23)}$ という説である。また，吉川広家 が出雲に移封された柵封時代（1591-1601年）に，その 領土であった隠岐の島の総庄屋の家で茶粥を食べた。そ の経験から，岩国へ移封した1602年（江戸時代）以降, 年貢米の不足に悩んだ祭に，広家は家臣に一日一回の茶 粥を奨励した24) という説もある。いずれの説も藩の命に よって節米目的で食べられたことに始まったようである。 山口県大島郡大島町ではサッマイモの入った茶粥を単に 「チャガユ」と呼び，吉川広家の時代から日常的に食べ られていた ${ }^{21)}$ 。茶粥にサツマイモを入れる習慣は島根県 石見地方でもみられたことから，島根県と山口県の茶粥 習慣には共通点が見出せることが期待できる。また，茶 粥の伝播経路や茶粥が食べられようになった理由が未だ 解明に至っていない。

そこで本論文では島根県と山口県の茶粥習俗の内容を 明らかにした。さらに島根県あるいは山口県と著者らが 以前に報告した近畿地方（和歌山県 · 奈良県 · 大阪府 . 京都府・滋賀県 $)^{3}$, 16)，三重県 ${ }^{16)}$ ，佐賀県17) との間の茶 粥習俗の共通点を見出すことを検討した。

\section{2. 調査方法}

\section{(1) 調査対象}

島根県, 山口県に在住して抢り, 老人福祉施設の利用 者, 老人クラブなどにアンケートの協力を依頼し, 了解
が得られた施設にアンケート用紙を送付して, 記入後, 返信してもらった。回収率は100\%であった。

\section{(2) 調査時期}

島根県 ; 聞き取り調査 : 隠岐の島町（2007年 3 月） 茶粥習俗調査：2004年 4 月から2004年 8 月

山口県 ; 聞き取り調査 : 大島町（1996年 8 月）, 岩国 市（1998年 6 月） 茶粥習俗調査：2003年 7 月から2003年11月

\section{(3) 調査内容}

茶粥に関するアンケート用紙を表 1 に示した。

\section{(4) 統計処理}

単純集計は, Microsoft Excelを用いて行った。単一 回答については度数と比率を示し, 複数回答については, 選択肢別にその選択肢が選ばれたか選ばれなかったかの 比率（以後, 選択率とする）を示した。また，集計值の 有意差は統計解析アドインソフト「エクセル統計 2000 for Windows」（SSRI）を用い, 二項検定, $\chi^{2}$ 検 定で解析し，有意水準は $5 \%$ とした。

\section{3. 調査結果}

\section{（1）対象者の年齢階層別比率}

対象者数と年齢階層別比率を表 2 に示した。年齢階層 別比率は島根県の方が山口県に比べて50歳代の割合が少 なく，70歳代の割合が多かったことから両県の間で有意 差が認められた。

\section{（2）島根県，山口県における茶粥を食べる習慣の分布}

表 3 に島根県抢よび山口県に扔ける茶粥を食べる習慣 の有無を示した。

島根県における「茶粥を食べる習慣がある」者 $(262$ 人）は「茶粥を食べる習慣がない」者（181人）に比べ て有意に高かった（ $\mathrm{p}<0.01 ）$ 。「茶粥を食べる習慣があ る」者のうち，「現在も食べている」者（53人）は，「か つて食べたことがある」者（209人）より有意に少なか った $(\mathrm{p}<0.01)$ 。

山口県では「茶粥を食べる習慣がある」者（280人） は，「茶粥を食べる習慣がない」者（59人）より有意に

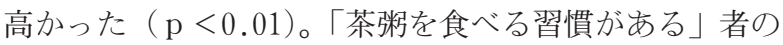
うち，「現在も食べている」者（109人）は「かつて食べ たことがある」者（171人）より有意に少なかった（ $\mathrm{p}$ $<0.01)$ 。

島根県と山口県の両県に拈いて「茶粥という言葉を聞 いたことがない」と回答をした者は「茶粥という言葉は 聞いたことがあるが習慣的には食べたことがない」と回 答した者よりも有意に少なかった（それぞれ $\mathrm{p}<0.01 ） 。$ 「茶粥を食べる習慣の有無」には島根県と山口県との間 に有意差が確認された $(\mathrm{p}<0.01)$ 。

次に島根県, 山口県に抢涂粥を食べる習慣の分布 を図 1 に示した。

島根県において茶粥を食べる習慣が最も多く見られた 地域は隠岐郡 (58人), 次いで邑智郡 (31人), 飯石郡 
質問 1 .

(1) かつて習慣として食べたことがある。

(2) 現在も習慣として食べている。

(3) 茶がゆという言葉は聞いたことはあるが食べたことがない。

(4) 茶がゆという言葉を聞いたことがない。

以下の質問は，質問 1 で(1)あるいは(2)と答えた方のみお答えください。

質問 2 . 茶がゆをいつ食べましたか。次の各項目に該当する番号を丸で囲んで下さい。 複数に丸をつけていただいて結構です。
(1) 朝食
(2) 10 時
（3）昼食
(4) 15 時
(5) 夕食
(6) その他

質問 3 。茶がゆに用いる茶についてお答え下さい。次の各項目に該当する番号を丸で囲んで下さい。

（1）今は番茶，昔はカワラケツメイ (2) 今はカワラケツメイ, 昔は番茶

（3）今も昔も番茶 （4）今も昔もカワラケツメイ （5）今は八ブ茶, 昔は番茶

（6）今は番茶，昔は八ブ茶（7）今も昔もハブ茶（8）その他（）

質問 4 . 茶がゆをつくる時，塩を入れますか。次の各項目に該当する番号を丸で囲んで下さい。
(1) 入れる
(2) 入れない

質問 5 . 茶がゆを食べる理由は何ですか。該当番号を丸で囲んで下さい。
(1) 美味しい
(2) からだによい
(3) 好き
(4) 単に習慣だから
（5）その他

質問 6 ．茶がゆの呼び方について拈聞きします。あなたの使っている呼び名の番号を丸で囲んで下さい。
(1) チャガユ
(2) チャガイ
(3) チャガエ
(4) アサチャ
(5) アサジャ
(6) オカユサン
(7) オカイサン
(8) コメジャ
(9)その他 (

質問 7 . 冷や飯に茶がゆをかけて食べる習慣はありますか。どちらかを丸で囲んで下さい。
(1) ある
(2) ない

質問 8 . 茶がゆには，さつまいも，やまいも，さといも，麦など，具を入れる習慣はありますか。 どちらかを丸で囲んで下さい。

(1) ある (2) ない

質問 9 ．質問 8 で(1)と答えた方にお聞きします。茶がゆに入れるものを丸で囲んで下さい。 複数でもかまいません。
(1)さつまいも
(2)さといも
(3) 空豆
(4) 大豆
(5) 黒豆
(6) 小豆
(7) かきもち
(8)もち
(9)ささげ
(10) ミカンの皮
(11) 昆布 (12) 生姜
(13) その他 (

質問10．茶がゆを作るときに使う道具についてお聞きします。 次の各項目に該当する番号を丸で囲んで下さい。
鍋類 : (1) 鉄鍋
(2) 茶鉒
(3) 羽釜
(4) 土鍋
(5)その他
茶袋：
(1) 使わない
(2) 使う

質問11，茶がゆを盛り付ける時の道具についてお聞きします。 次の各項目に該当する番号を丸で囲んで下さい。
(1)しゃもじ
(2) 竹製柄杓
（3）金属製玉杓子
(4) その他

質問12. 茶がゆは節米目的に食べられたと思われますか。 次の各項目に該当する番号を丸で囲んで下さい。
(1) 思う
(2) 思わない
(3)わからない 
日本食生活学会誌 Vol.19 No.1（2008）

表 2 対象者数と年齢階層別比率

\begin{tabular}{|c|c|c|c|c|c|c|}
\hline & \multirow{2}{*}{$\begin{array}{l}\text { 対象者数 } \\
\text { (人) }\end{array}$} & \multicolumn{5}{|c|}{ 年齢階層別比率（\%) } \\
\hline & & 50歳代 & 60歳代 & 70歳代 & 80 歳以上 & 不明 \\
\hline 島根県 & 443 & 6.5 & 12.0 & 32.5 & 49.0 & - \\
\hline 山口県 & 339 & 13.0 & 10.9 & 24.5 & 47.5 & 4.1 \\
\hline \multicolumn{2}{|c|}{$\begin{array}{l}\text { 島根県 } \\
\text { 対 } \\
\text { 山口県 }\end{array}$} & \multicolumn{5}{|c|}{$\begin{array}{l}\chi^{2}=31.34 \quad(\mathrm{p}<0.01) \\
\text { 調整済残差検定により } \\
\text { 高い } \quad \text { 低い }\end{array}$} \\
\hline
\end{tabular}

表 3 茶粥を食べる習慣の有無

\begin{tabular}{|c|c|c|c|c|c|c|c|c|c|}
\hline & \multirow[b]{2}{*}{ 習慣あり } & \multirow[b]{2}{*}{ 習慣なし } & \multirow[b]{2}{*}{$\begin{array}{l}\text { 「習慣なし」 } \\
\text { 対して }\end{array}$} & \multicolumn{2}{|c|}{ 習慣あり } & \multirow[b]{2}{*}{$\begin{array}{c}\text { 「現在も…」 } \\
\text { に } \\
\text { 対して }\end{array}$} & \multicolumn{2}{|c|}{ 習慣なし } & \multirow[b]{2}{*}{ 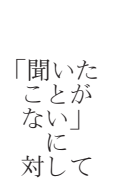 } \\
\hline & & & & $\begin{array}{l}\text { かつて習慣としど } \\
\text { て食べたど゙ } \\
\text { ある }\end{array}$ & 現在も習慣とし & & $\begin{array}{l}\text { 茶弱という言葉 } \\
\text { は聞いたこと唯 } \\
\text { あるが習的に } \\
\text { は食べたととが } \\
\text { ない }\end{array}$ & $\begin{array}{l}\text { 茶挡という言葉 } \\
\text { 势いたこと聞いた } \\
\text { ない }\end{array}$ & \\
\hline 島根県 ( $\mathrm{n}=443)$ & $59.1^{* *}$ & 40.9 & \multirow{2}{*}{$* * \mathrm{p}<0.01$} & $79.8^{* *}$ & 20.2 & \multirow{2}{*}{$* * \mathrm{p}<0.01$} & $86.7^{* *}$ & 13.3 & \multirow{2}{*}{$* * \mathrm{p}<0.01$} \\
\hline 山口県 ( n =339) & $82.6^{* *}$ & 17.4 & & $61.1^{* *}$ & 38.9 & & $88.1^{* *}$ & 11.9 & \\
\hline $\begin{array}{l}\text { 島根県 } \\
\text { 対 } \\
\text { 山口県 }\end{array}$ & \multicolumn{3}{|c|}{$\begin{array}{c}\chi^{2}=49.66(\mathrm{p}<0.01) \\
\text { 調整済残差検定により } \\
\square \text { 高い } \square \text { 低い }\end{array}$} & \multicolumn{3}{|c|}{$\begin{array}{c}\chi^{22}=22.59 \quad(\mathrm{p}<0.01) \\
\text { 調整済残差検定により } \\
\text { 高い } \square \text { 低い }\end{array}$} & \multicolumn{3}{|c|}{ n.s. } \\
\hline
\end{tabular}

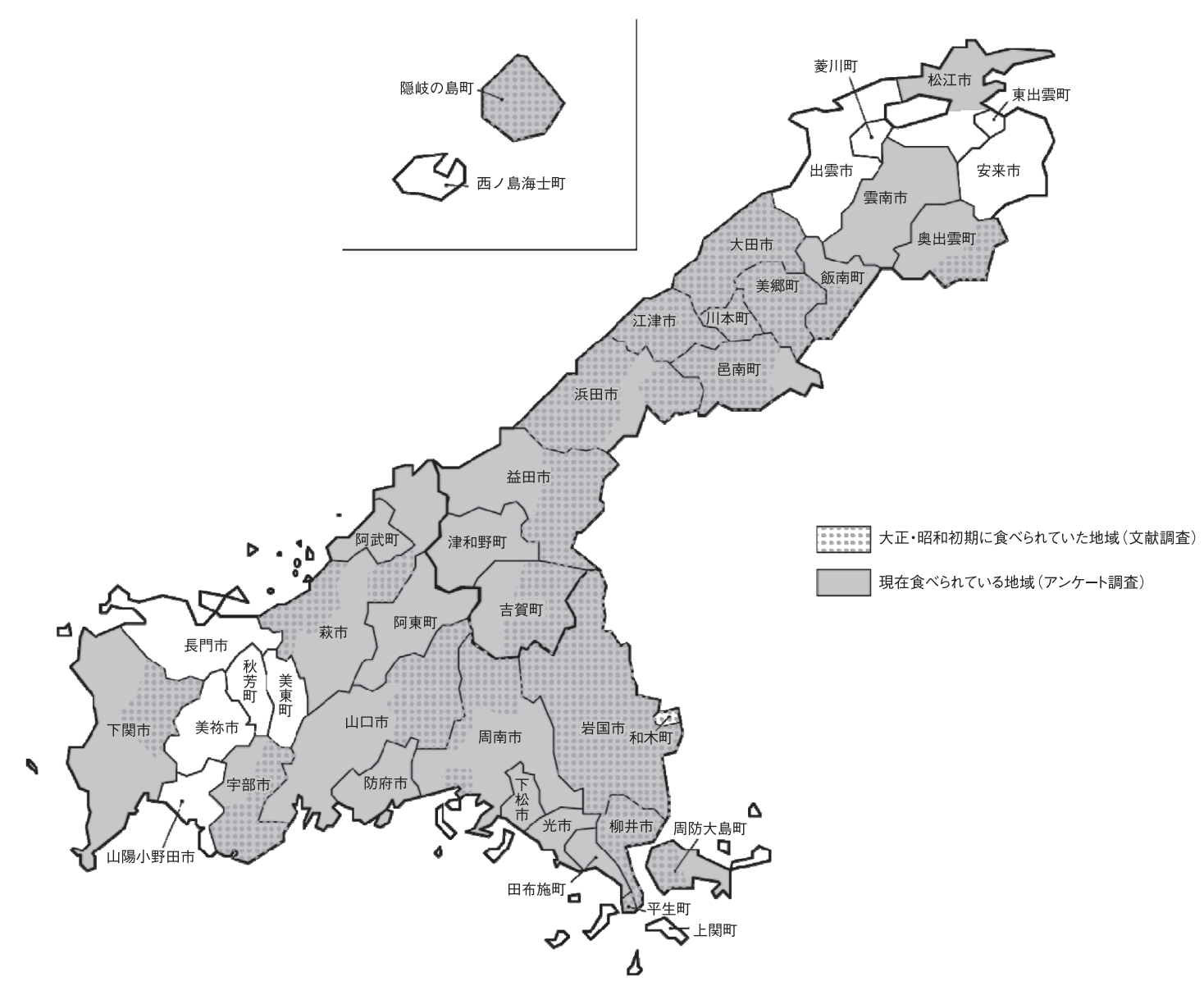


島根県·山口県の茶粥習俗

表 4 茶粥を食べる時間帯

$(\%)$

\begin{tabular}{|c|c|c|c|c|c|c|c|}
\hline & 朝食 & 10時 & 昼食 & 15時 & 夕食 & その他 & $\begin{array}{l}\text { 「朝食」 } \\
\text { に刘して }\end{array}$ \\
\hline 島根県 & 57.5 & $1.6^{* *}$ & $8.8^{* *}$ & $6.2^{* *}$ & $22.5^{* *}$ & $3.4^{* *}$ & $* * \mathrm{p}<0.01$ \\
\hline 山口県 & 52.6 & $1.9^{* *}$ & $15.8^{* *}$ & $2.5^{* *}$ & $22.1^{* *}$ & $5.1^{* *}$ & \\
\hline $\begin{array}{l}\text { 島根県 } \\
\text { 対 } \\
\text { 山口県 }\end{array}$ & \multicolumn{6}{|c|}{$\begin{array}{c}\chi^{2}=12.51 \quad(\mathrm{p}<0.05) \\
\text { 調整済残差検定により } \\
\text { 高い } \quad \text { 低い }\end{array}$} & \\
\hline
\end{tabular}

表 5 茶の種類

(\%)

\begin{tabular}{|c|c|c|c|c|c|c|c|c|c|}
\hline & $\begin{array}{l}\text { 今も暮も } \\
\text { 番茶 }\end{array}$ & $\begin{array}{c}\text { 今 : 番茶 } \\
\text { 昔 } \\
\text { ツメイ } \\
\text { ツメ }\end{array}$ & \begin{tabular}{|c|} 
今 : カワラケ \\
ッメイ \\
昔: 番茶 \\
\end{tabular} & $\begin{array}{c}\text { 今も昔も } \\
\text { カワラケ } \\
\text { ツメイ }\end{array}$ & $\begin{array}{l}\text { 今：ハブ茶 } \\
\text { 昔：番茶 }\end{array}$ & $\begin{array}{c}\text { 今 : 番茶 } \\
\text { 昔: 余 }\end{array}$ & $\begin{array}{l}\text { 今も昔も } \\
\text { バ゙茶 }\end{array}$ & その他 & \begin{tabular}{|l} 
「今も昔も番 \\
茶」に対し
\end{tabular} \\
\hline 島根県 & 82.2 & $4.3^{* *}$ & $0.8^{* *}$ & $2.8^{* *}$ & $2.4^{* *}$ & $0.4^{* *}$ & $0.0^{* *}$ & $7.1^{* *}$ & \multirow{2}{*}{$* * \mathrm{p}<0.01$} \\
\hline 山口県 & 51.9 & $4.2^{* *}$ & $0.8^{* *}$ & $6.1^{* *}$ & $6.5^{* *}$ & $5.0^{* *}$ & $9.9^{* *}$ & $15.6^{* *}$ & \\
\hline $\begin{array}{l}\text { 島根県 } \\
\text { 対 } \\
\text { 山口県 }\end{array}$ & & & & $\begin{array}{c}\chi^{2}=68.97 \\
\text { 調整済残 } \\
\text { 高し }\end{array}$ & $\begin{array}{l}\mathrm{p}<0.01) \\
\text { 定により } \\
\text { 低い }\end{array}$ & & & & \\
\hline
\end{tabular}

(28人)，鹿足郡 $(28$ 人)，那賀郡 $(27$ 人)，大原郡 $(19$ 人), 益田市 (18人)，大田市（17人)，江津市（16人)，浜田 市 $(7$ 人), 仁多郡 $(7$ 人)，松江市（ 7 人）であった。 山口県に括いて茶粥を食べる習慣が最も多く確認でき た地域は大島郡 $(85$ 人)，次いで宇部市（31人)，吉敷郡 (30人), 熊毛郡 (20人), 㺵珂郡 (16人), 柳井市 (16人), 阿武郡 (14人), 防府市 (14人), 徳山市 (11人), 下関 市 $(11$ 人), 光市 $(9$ 人), 佐波市 $(8$ 人), 岩国市 $(6$ 人), 新南陽市 ( 6 人), 山口市 $(6$ 人) であり, 茶粥を 食べる習慣は広範囲に分布していた。

\section{（3）島根県, 山口県における茶粥習俗の特徵 \\ 1）茶粥を食べる時間帯}

茶粥を食べた時間帯を食事機会別に検定し，その結果 を表 4 に示した。島根抢よび山口の両県に抢ける茶粥の 食事時間帯では，特に「朝食」に食べた者の割合が最も 多く（島根県 $57.5 \%$, 山口県 $52.6 \%$ ), 「夕食」(島根県： $22.5 \%$; 山口県 : $22.1 \%$ ） や「昼食」（島根県 : $8.8 \%$; 山口県：15.8\%）に比べて有意に高かった（ $\mathrm{p}<0.01 ） 。$ 食事以外の時間帯ではあまり食べられていなかった。

\section{2）茶の種類}

茶粥に用いる茶の種類の結果を表 5 に示した。「番茶」 と答えた者が島根県 $82.2 \%$, 山口県 $51.9 \%$ であり, 両県 とも「カワラケツメイ」抢よび「ハブ茶 (マメ茶)」の 使用頻度は「番茶」のそれに比べて有意に低かった（そ れぞれ $\mathrm{p}<0.01)$ 。番茶以外では両県とも「カワラケツ メイ」や「ハブ茶」を使用していた。

\section{3）塩を入れる習慣の有無}

茶粥に塩を入れる習慣の有無を表 6 に示した。島根県 では「入れる」と答えた者の割合が $84.0 \%$ でり，「入
表 6 塩を入れる習慣の有無

(\%)

\begin{tabular}{|c|c|c|c|}
\hline & 入れる & 入れない & \begin{tabular}{|l} 
「入れない」 \\
に対して
\end{tabular} \\
\hline 島根県 & $84.0^{* *}$ & 16.0 & \multirow{2}{*}{$* * \mathrm{p}<0.01$} \\
\hline 山口県 & $37.4^{* *}$ & 62.6 & \\
\hline $\begin{array}{l}\text { 島根県 } \\
\text { 対 } \\
\text { 山口県 }\end{array}$ & \multicolumn{2}{|c|}{$\begin{array}{c}\chi^{2}=113.63(\mathrm{p}<0.01) \\
\text { 調整済残差検定により } \\
\text { 高い }\end{array}$} & \\
\hline
\end{tabular}

れない」に比べて有意に高かった（ $\mathrm{p}<0.01 ） 。$

一方, 山口県では「入れない」と答えた者の割合が 62.6\%であり，「入れる」に比べて有意に高かった（p $<0.01)$ 。

「塩を入れる習慣の有無」では島根県と山口県の両県 の間で有意な差が認められた（ $\mathrm{p}<0.01 ） 。$

\section{4）茶粥を食べる理由}

茶粥を食べる理由を表 7 に示した。「おいしい，好き， 身体によい」を「積極的理由」に分類し,「習慣」であ るを「消極的理由」に分類すると,「積極的理由」を挙 げた者が島根県 $51.9 \%$ ，山口県 $59.3 \%$ であり，いずれの 県でも「積極的理由」の方が「消極的理由」よりも有意

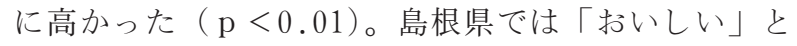
「身体によい」あるいは「好き」との間にそれぞれ有意 な差が認められた（「身体によい」： p <0.05;「好き」： $\mathrm{p}<0.01)$ 。この傾向は山口県でも同様に観察された。

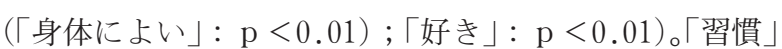
という消極的な理由は, 島根県では $33.2 \%$, 山口県では $30.4 \%$ を占めた。 


\begin{tabular}{|c|c|c|c|c|c|c|c|c|c|}
\hline & \multirow{2}{*}{$\begin{array}{l}\text { 積極的 } \\
\text { 理由 }\end{array}$} & \multirow{2}{*}{$\begin{array}{l}\text { 消極的 } \\
\text { 理由 }\end{array}$} & \multirow{2}{*}{$\begin{array}{c}\text { 「消極的理由」 } \\
\text { に対して }\end{array}$} & \multicolumn{3}{|c|}{ 積極的理由 } & \multirow{2}{*}{\begin{tabular}{|c|} 
消極的理由 \\
習慣 \\
\end{tabular}} & \multirow{2}{*}{ その他 } & \multirow{2}{*}{$\begin{array}{l}\text { 「おいしい」 } \\
\text { に対して }\end{array}$} \\
\hline & & & & おいしい & 身体によい & 好き & & & \\
\hline 島根県 & $51.9^{* *}$ & 33.2 & \multirow{2}{*}{$* * \mathrm{p}<0.01$} & 25.0 & $17.9^{*}$ & $9.0^{* *}$ & $33.2^{*}$ & $14.9^{* *}$ & \multirow{2}{*}{$\begin{array}{r}* * \mathrm{p}<0.01 \\
* \mathrm{p}<0.05\end{array}$} \\
\hline 山口県 & $59.3^{* *}$ & 30.4 & & 28.2 & $18.2^{* *}$ & $12.9^{* *}$ & $30.4^{*}$ & $10.3^{* *}$ & \\
\hline $\begin{array}{l}\text { 島根県 } \\
\text { 対 } \\
\text { 山口県 }\end{array}$ & \multicolumn{3}{|c|}{ n.s. } & \multicolumn{6}{|c|}{ n.s. } \\
\hline
\end{tabular}

\section{表 8 茶粥の呼び名（複数回答）}

\begin{tabular}{|c|c|c|c|c|c|c|c|c|c|}
\hline & チャガユ & チャガイ & オカイサン & オカユサン & チャガエ & アサジャ & アサチャ & その他 & 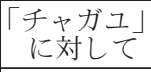 \\
\hline 島根県 & 42.1 & 45.5 & $3.8^{* *}$ & $2.6^{* *}$ & $2.6^{* *}$ & $1.1^{* *}$ & $0.4^{* *}$ & $1.9^{* *}$ & \multirow{2}{*}{${ }^{* *} \mathrm{p}<0.01$} \\
\hline 山口県 & 45.4 & $28.7^{* *}$ & $13.0^{* *}$ & $7.2^{* *}$ & $0.3^{* *}$ & $0.0^{* *}$ & $0.0^{* *}$ & $5.4^{* *}$ & \\
\hline $\begin{array}{c}\text { 島根県 } \\
\text { 対 } \\
\text { 山口県 }\end{array}$ & & & & $\begin{array}{c}\chi^{2}=36.82 \\
\text { 調整済残差検 } \\
\square \text { 高い }\end{array}$ & $\begin{array}{c}\mathrm{p}<0.01 ） \\
\text { 定により } \\
\text { 低い }\end{array}$ & & & & \\
\hline
\end{tabular}

「その他」として, 両県とも節米目的, 食糧不足, 食 ベやすい等の理由が挙げられていた。

また，茶粥を食べる理由について，山口県と島根県と の間には有意差は認められなかった。

\section{5）䒩粥の呼び名}

茶粥の呼び名を表 8 に示した。

島根県では「チャガイ」（45.5\%）と「チャガユ」 (42.1\%) が同程度に用いられ，これらをあわせると $87.6 \%$ であり，「オカイサン」(3.8\%),「オカユサン」 (2.6\%) の合計 $(6.4 \%)$ に比べて有意に高かった（p $<0.01)$ 。

山口県では「チャガユ」(45.4\%) の方が「チャガイ」 (28.7\%) よりも多く用いられていた（ $\mathrm{p}<0.01) 。$ 。た, 「チャガユ」と「チャガイ」をあわせると $74.1 \%$ を達し， 「オカイサン」 $(13.0 \%)$,「オカユサン」 (7.2\%) の合計 (20.2\%) に比べて有意に高かった（ $\mathrm{p}<0.01)$ 。

島根県と山口県の間で茶粥の呼び方に有意差が認めら れた $(\mathrm{p}<0.01)$ 。

6） ツヶゴハンの習慣の有無

\begin{tabular}{|c|c|c|c|}
\hline & 習慣あり & 習慣なし & $\begin{array}{l}\text { 「習慣なし」 } \\
\text { に対して }\end{array}$ \\
\hline 島根県 & $24.5^{* *}$ & 75.5 & \multirow{2}{*}{$* * \mathrm{p}<0.01$} \\
\hline 山口県 & 47.3 & 52.7 & \\
\hline $\begin{array}{c}\text { 島根県 } \\
\text { 対 } \\
\text { 山口県 }\end{array}$ & \multicolumn{2}{|c|}{$\begin{array}{l}\chi^{2}=42.46 （ \mathrm{p}<0.01 ） \\
\text { 調整済残差検定により }\end{array}$} & \\
\hline
\end{tabular}

ツケゴハンの習慣の有無を表 9 に示した。ツケゴハン とは残り飯に茶粥をかけて食べることである。ツケゴ八 ンの習慣が「ない」と答えた者の割合 $(75.5 \%)$ は島根 県では「ある」と答えた者の割合 $(24.5 \%)$ よりも有意 に高かった（ $\mathrm{p}<0.01 ） 。 一$ 方, 山口県では「ない」と 答えた者の割合 $(52.7 \%)$ は，「ある」と答えた者の割 合 $(47.3 \%)$ との間には有意な差が認められなかった。

ツケゴハンの習慣は島根県と山口県の間で有意差が認 められた $(\mathrm{p}<0.01)$ 。

\section{7）茶粥に具を入れる習慣および具の種類}

茶粥に具を入れる習慣の有無抢よび具の種類を表 10 に 示した。茶粥に「具を入れる」習慣の有無に対して, 「具を入れる」と答えた者の割合は島根県 $74.0 \%$, 山口 県 $81.1 \%$ であり，いずれの県でも「具を入れる」方が 「具を入れない」よりも有意に高かった（それぞれ $\mathrm{p}<$ $0.01)$ 。

「サッマイモ」の使用頻度は島根県 $50.5 \%$, 山口県 43.8\%であり, いずれの県においてもサッマイモ以外の 具材の使用頻度に比べてはるかに高かった（それぞれ $\mathrm{p}$ $<0.01)$ 。

サッマイモに次いで使用頻度の高かった具材は, 島根 県では「モチ」(13.3\%)「ソラマメ」(9.0\%),「アズキ」 (8.7\%), 山口県では「モチ」(17.7\%),「カキモチ」 $(12.9 \%), 「 ソ ラ マ メ 」(7.2 \%), 「 ア ス ゙ キ 」(4.8 \%)$ で あり，両県に共通点が多くみられた。

島根県と山口県の間で茶粥に入れる具材に有意差が認 められた $(\mathrm{p}<0.01)$ 。

8）茶粥を作るために用いる道具

茶粥を作るための道具について, 鍋類については表11 


\begin{tabular}{|c|c|c|c|c|c|c|c|c|c|c|c|c|c|c|c|c|c|}
\hline & 習慣あり & 習慣なし & 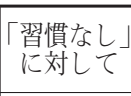 & $\begin{array}{l}\text { サツマ } \\
\text { イ壬 }\end{array}$ & モチ & $\begin{array}{l}\text { ソラ } \\
\text { マメ }\end{array}$ & $\begin{array}{l}\text { アズ } \\
\text { キ }\end{array}$ & $\begin{array}{l}\text { サト } \\
\text { イモ }\end{array}$ & $\begin{array}{l}\text { ダイ } \\
\text { ズ }\end{array}$ & $\begin{array}{l}\text { クロ } \\
\text { マメ }\end{array}$ & $\begin{array}{l}\text { カキ } \\
\text { 乇チ }\end{array}$ & ブン & \begin{tabular}{|l} 
ササ \\
ゲ
\end{tabular} & $\begin{array}{l}\text { シ寻 } \\
\text { ヴ }\end{array}$ & 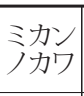 & $\begin{array}{l}\sum_{\text {他の }} \\
\text { 他 }\end{array}$ & $\begin{array}{l}\text { 「サツマイモ」 } \\
\text { 以外の呼び名 } \\
\text { に対して }\end{array}$ \\
\hline 島根県 & $74.0^{* *}$ & 26.0 & \multirow{2}{*}{$* * \mathrm{p}<0.01$} & $50.5^{* *}$ & 13.3 & 9.0 & 8.7 & 5.6 & 2.8 & 1.6 & 0.6 & 0.6 & 0.3 & 0.3 & 0.0 & 6.7 & \multirow{2}{*}{$* * \mathrm{p}<0.01$} \\
\hline 山口県 & $81.1^{* *}$ & 18.9 & & $43.8^{* *}$ & 17.7 & 7.2 & 4.8 & 2.0 & 2.4 & 1.7 & 12.9 & 1.1 & 2.0 & 0.4 & 0.2 & 3.8 & \\
\hline $\begin{array}{l}\text { 島根県 } \\
\quad \text { 対 } \\
\text { 山口県 }\end{array}$ & \multicolumn{3}{|c|}{ n.s. } & \multicolumn{13}{|c|}{$\begin{array}{c}\left.\chi^{2}=62.02 （ \mathrm{p}<0.01\right) \\
\text { 調整済残差検定により } \\
\text { 高い 低い }\end{array}$} & \\
\hline
\end{tabular}

表11一1 茶粥を作るために用いる道具

$(\%)$

\begin{tabular}{|c|c|c|c|c|c|c|}
\hline & 鉄鍋 & 羽釜 & 土鍋 & 茶釜 & その他 & 「鉄鍋」に対して \\
\hline 島根県 & 40.2 & $25.4^{* *}$ & $23.5^{* *}$ & $4.9^{* *}$ & $6.1^{* *}$ & \multirow{2}{*}{$\begin{array}{l}* * \mathrm{p}<0.01 \\
* \mathrm{p}<0.05\end{array}$} \\
\hline 山口県 & 22.7 & $31.7^{*}$ & 16.9 & 18.0 & $10.8^{* *}$ & \\
\hline $\begin{array}{c}\text { 島根県 } \\
\text { 対 } \\
\text { 山口県 }\end{array}$ & \multicolumn{5}{|c|}{$\begin{array}{l}\left.\chi^{2}=41.51 （ \mathrm{p}<0.01\right) \\
\text { 調整済残差検定により }\end{array}$} & \\
\hline
\end{tabular}

\begin{tabular}{|c|c|c|c|}
\hline & 表11-2 & 茶袋の使月 & $(\%)$ \\
\hline & 使う & 使わない & 「使わない」に対して \\
\hline 島根県（ $\mathrm{n}=262 ）$ & $63.9^{* *}$ & 36.1 & \multirow{2}{*}{$* * \mathrm{p}<0.01$} \\
\hline 山口県（n = 275） & $84.8^{* *}$ & 15.2 & \\
\hline $\begin{array}{c}\text { 島根県 } \\
\text { 対 } \\
\text { 山口県 }\end{array}$ & \multicolumn{2}{|c|}{$\begin{array}{l}\chi^{2}=25.77 （ \mathrm{p}<0.01 ） \\
\text { 調整済残差検定により }\end{array}$} & \\
\hline
\end{tabular}

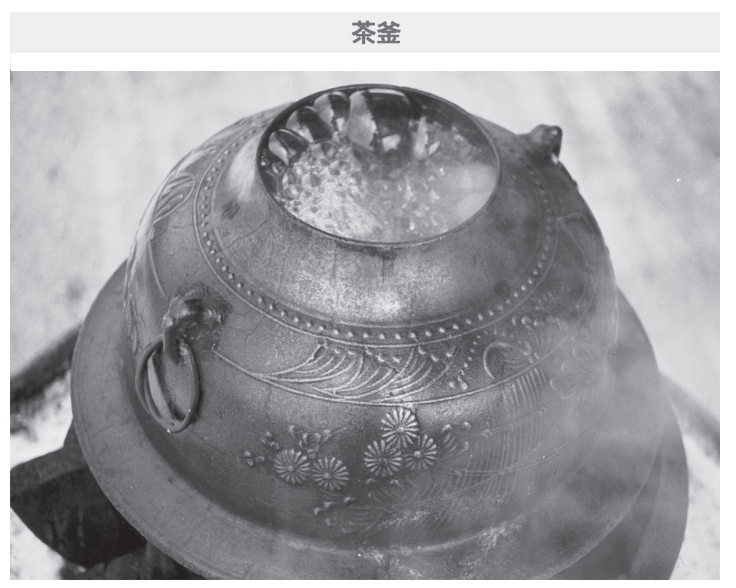

写真 1 茶釜（山口県 1996年）

- 1 ，茶袋の使用頻度については表11- 2 に示した。 島根県では「鉄鍋」(40.2\%) の使用頻度が最も高く， 次いで「羽釜」(25.4\%)，「土鍋」(23.5\%) であった。 鉄鍋と羽釜，土鍋あるいは茶釜との間にそれぞれ有意な 差が認められた（「羽鉒」 $\mathrm{p}<0.01 ;$ 鍋」： $\mathrm{p}<0.01$; 「茶釜」： $\mathrm{p}<0.01)$ 。「茶釜」の使用頻度は $4.9 \%$ であり， 表には示していないが，「羽釜」抢よび「土鍋」との間 にそれぞれ有意差が認められた（「羽釜」 $\mathrm{p}<0.01 ;$ 「土 鍋」: $\mathrm{p}<0.01)$ 。

山口県では「羽釜」（31.7\%）の使用頻度が最も高く， 「鉄鍋」(22.7\%) との間に有意な差が認められた（「鉄
表12 茶粥に対する意識

(\%)

\begin{tabular}{|c|c|c|c|c|}
\hline & \multicolumn{3}{|c|}{ 茶码は節米目的に食べられたと } & \multirow{2}{*}{$\begin{array}{l}\text { 「思わない」 } \\
\text { に対して }\end{array}$} \\
\hline & 思う & 思わない & わからない & \\
\hline 島根県 & $70.7^{* *}$ & 17.3 & 12.0 & \multirow{2}{*}{${ }^{* *} \mathrm{p}<0.01$} \\
\hline 山口県 & $48.4^{* *}$ & 36.8 & 14.7 & \\
\hline $\begin{array}{l}\text { 島根県 } \\
\text { 対 }\end{array}$ & \multicolumn{3}{|c|}{$\begin{array}{l}\chi^{2}=29.03(\mathrm{p}<0.01) \\
\text { 調整済残差検定により }\end{array}$} & \\
\hline 山口県 & & 高い & 低い & \\
\hline
\end{tabular}

鍋」： p <0.05)。女た表には示していないが「羽釜」と 「茶釜」の間にも有意差が認められた（「茶釜」： p < 0.01)。島根県と山口県の間で茶粥を作るための道具に 有意差が認められた $(\mathrm{p}<0.01)$ 。

茶袋については「使う」と答えた者の割合が島根県 63.9\%，山口県 $84.8 \%$ であり，いずれの県に抢いても 「使わない」よりも有意に高かった（それぞれ $\mathrm{p}<0.01 ） 。$ また, 表には示していないが島根県よりも山口県の方が 茶袋の使用頻度は有意に高かった（ $\mathrm{p}<0.01 ） 。$

\section{9）茶粥に対する意識}

茶粥に対する意識の結果を表12に示した。茶誁が節米 目的で食べられようになった，と思うかどうかに関する 質問に対し，「思う」と答えた者は島根県 $70.7 \%$, 山口 県 $48.4 \%$ であったのに対して，「思わない」と答えた者 はそれぞれ $17.3 \% ， 36.8 \%$ であったいずれの県でも節 米目的であったと「思う」者の割合が「思わない」と答 
えた者に比べて有意に高かった（それぞれ $\mathrm{p}<0.01 ） 。$ 特に茶粥を，節米目的で食べるようになったという意識 は, 島根県と山口県との間で有意な差が認められた（p $<0.01)$ 。

\section{（4）島根県隱岐の島町五箇村の茶粥}

緒言で述べたように山口県の茶粥は隠岐の島から伝わ ったという説があることから，隠岐の島における茶张に 関する現地調査を行った。隠岐の島は茶の木の生育に適 している。茶䉼習俗が濃厚にみられた都万目は，現地調 查をした 2007 年 3 月時点ではかつての茶園は杉林になっ ており，その杉林の下には茶の木が育ち（写真 2 ), 今 でも手作りで番茶が作られ，茶颟が食べられていた。

五箇村在住の田崎初江さん (81歳), 村上フサ子さん （78歳）から聞き取った茶继（写真 3 ）の作り方は次の ようであった。

番茶は田植えが終わり，少し暇になった $6-7$ 月頃， 茶を枝ごと刈り取り, $5 \mathrm{~cm}$ くらいに切り, 蒸す。䇥に 広げてもんだあと, 天日で乾懆させて，保存した。使用 時に炒った。番茶をそのまま，湯に投じて煮出し，茶䉼 を作った。昔は囲炉裏にかけた鉄なべで作った。茶粥を コメから作った場合の所要時間は約40分であった。田崎

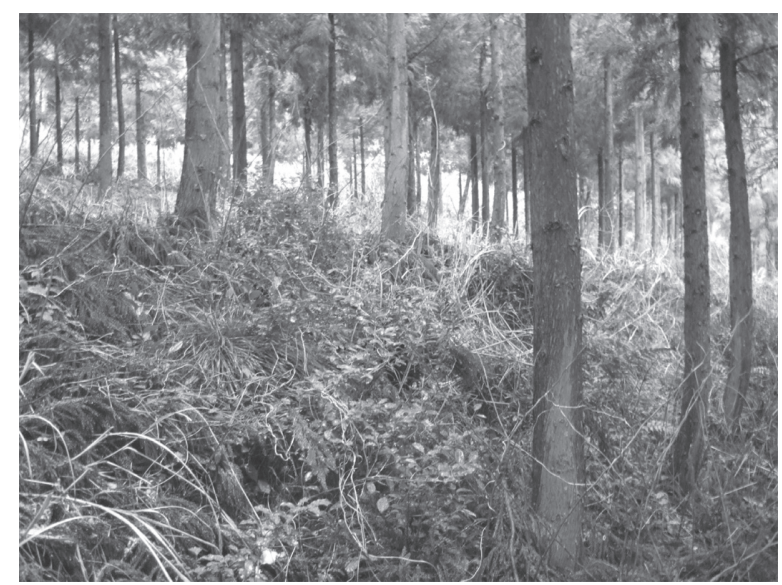

写真 2 隠岐の島の茶畑跡（2007年 3 月）

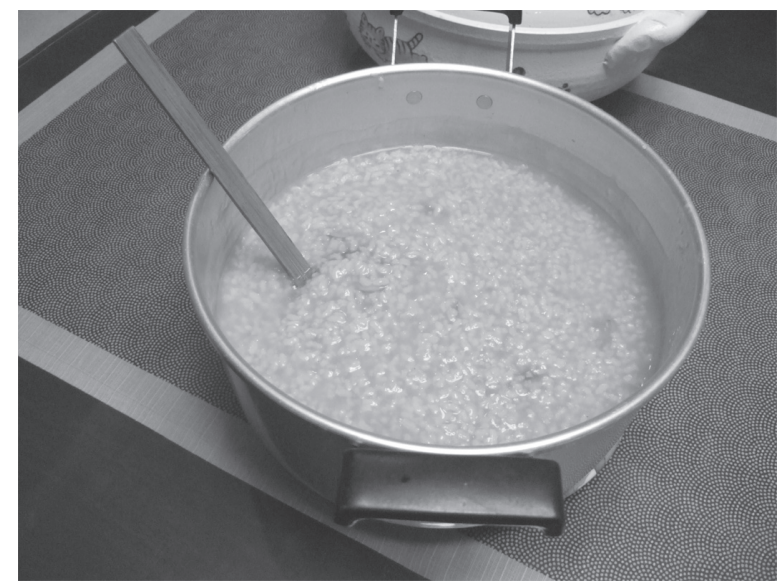

写真 3 隠岐の島の茶继（2007年）
さんは今でも毎朝茶粥を食べているが，若い者は食べな いという。茶䋆には炒った大豆を入れる場合も多く，香 ばしさが加わり一段とおいしくなるということであった。

\section{4. 考察}

島根県に扔いて，大正初年に茶弹が食べられていた地 域（括弧内には現在の地名を記した）は，五箇村・都万 村 (隠岐の島町), 匹見町 (益田市), 三隅町 ·弥栄村 · 旭町 (浜田市), 瑞穂町 (邑南町), 邑智町 (美郷町), 浜田市, 江津市 - 桜江町 (江津市), 大田市 $\cdot$ 仁摩町 (大田市), 横田町 (仁多郡南出雲町) であった ${ }^{25)}, 26$ 。 また町史・郡誌277-39) によると都万村, 西郷町（隠岐の 島町), 六日市町 (鹿足郡吉賀町), 匹見町（益田市）, 浜田市 - 旭町 (浜田市), 桜江町 - 石見 (邑智郡邑南町), 川本町 (邑智郡邑南町), 大和村 ((邑智郡美郷町), 江 津市, 温泉津町 (大田市), 赤来町（飯石郡飯南町）で 茶粘が食べられていたことが報告されている。これらの 地域を著者らの調查結果とともに図 1 に示した。文献と 著者らの調查結果はよく一致し, 島根県では茶粥習俗が 広範囲に分布していたことが再確認できた。今回の調査 で新たに加わった地域は津和野町, 雲南市, 松江市であ ったが，人数的にも少なく，文献でもこれらの地域に茶 粥習俗の存在が認められなかったことから, 津和野町, 雲南市, 松江市における茶张習俗は茶陠習俗のあった地 域からの移動によるものと考えられる。

島根県の中でも石見地方 (大田市, 邑智郡, 江津町, 浜田市，益田市，鹿足郡）や燰岐島後（隠岐の島町）で は特に茶张が多く食べられた地域であり，時にはコメの 代わりにムギを入れた茶粥も食べられていた25)。ムギを 入れた茶粥は和歌山県 (龍神村40) - 美山村41) - 清水町42) , 三重県 ${ }^{43}$, 奈良県44)でも食べられていた。隠岐島後は水 田が少ないため，コメ以外の穀物，才オムギやコムギ， イモ類を主食としていた時代が長かったが，明治・大 正・昭和へ移るにつれてコメの消費が徐々に増えた。ム ギ 8 割にコメ 2 割程度のムギ飯を食べていた時代（明治 の末から大正時代）では，茶粥はコメのある，またゆと りのある家の食べ物であった ${ }^{45}$ ) という報告もある。この ことからコメだけで作った茶邪を食べるようになるまで には，ムギだけ，あるいはコメとムギの混じった茶䋆が 食べられていたことが考光られた。茶邪に具が入れられ た理由は節米のための増量剤的意味があったと思われる。 また隠岐島後よりももっと水田が少なかった島前（西の 島町，海士町，知夫村）で茶张習俗が見られなかったの は，コメ不足のため茶䉼すら食べることができなかった からであろう。

隠岐の島に打ける茶弹習俗は次の事項が考えられる。 山形県の庄内地方・酒田では関西地方の影響を受けて朝 に粥（茶䉼の記述はない）を食べる習慣があり46)，また 新潟県佐渡島では茶张を食べる習慣が残っている47) 49)。 これらの地域は西日本型食文化の飛び地とされており,

$40 \quad(40)$ 
北前船の影響が強い地域である ${ }^{50)}$ 。北前船の航路が開け た元禄以降, 京都, 大阪には日本海沿岸の青森 · 秋田 · 庄内・越後・越中・加賀・越前からコメが供給されてい た。これらの地域間では物資たけではなく，たとえば佐 渡島の正月の雑者餅は西日本と同様に丸型であるという ように，食文化の交流も盛んに行われていたであろう。 隠岐の島も佐渡島と同様に北前船の寄港地であった ${ }^{51)}$ 。 隠岐の島で庄屋が食べていた茶粥は北前船によって大阪 からもたらされた可能性も考えられる。なぜなら隠岐の 島のアンケートの結果や聞き取り調査の結果から隠岐の 島では茶粥は朝食によく食べられていたことや茶粥の呼 び名は「チャガユ」「チャガイ」が最も多かったことな ど，大阪と隠岐の島の茶粥に共通点がみられたからであ る。

山口県で茶粥を常食としていた地域を図 1 に示したが, 岩国藩内の岩国市，柳井市，大島郡（大島郡周防大島町）, 熊毛郡平生町, 鹿野郡鹿野町 - 新南陽市 (周南市), 宇 部市，豊浦郡豊田町（下関市），佐波郡（山口市徳地町）, 阿武隈郡むつ久村 (萩市) - 萩を中心とした北浦地区の 一部だとされている ${ }^{52 \sim 55)}$ 。文献と著者らの結果とは一 致する地域が多かった。

吉川広家（山口県岩国市）が藩主であった頃（江戸時 代）の封建社会では封鎖的な経済機構が存在しており， ある地方に凶作があった時，その他の地方ではコメが凶 作地域に流出して，その結果コメの值上がりや食料不足 をきたすことがある。これを恐れて，藩主はコメの移出 停止を命じた。したがって凶作の打撃の大きい藩では, 飢饉による打撃を強く蒙ることになった ${ }^{56)}$ 。このような 封建社会の封鎖的な経済機構が，領地を減らされ節米を 必要とした吉川広家の茶粥奨励の原因のひとつであった かもしれない。大島町妙善寺では飢饉や災害の時, 難民 に茶粥が施されていた ${ }^{23)}$ 。著者らの1996年の山口県岩国 市に抢ける聞き取り調査の結果 ${ }^{57)}$ から「万徳院の茶粥」 として有名な岩国市の吉川藩の菩提寺万徳院（真宗）は 飢饉や水害時に茶粥を施していたことがわかった。これ らのことからも茶粥が節米目的に食べられていたことが 推測できる。

黒崎の分類 ${ }^{58)}$ によと明治初期の島根県と山口県の米 食率はそれぞれ35\%以上と $45 \%$ 以上であったという。米 食率の低い島根県の方がより節米を必要としていたであ ろう。今回の調査結果に扔いて，米食率の低かった島根 県の方が山口県よりも茶粥を節米目的で食べたと思って いる者の割合が高かったが，これには島根県の米食率の 低さが一因していると考えられる。茶粥習俗のある人た ちにとって，茶粥は貧しい時の食べ物であったという意 識が強いことが示唆された。また，著者らのこれまでの 調査地域3),16),17)同様に島根県や山口県においても, 茶 粥は節米のために食べられてきた食べ物であるという認 識を持ちながらも，コメの豊富な現在でも食べられてき た理由は人々の嗜好性によく合い，健康にもよいからで
あると推測される。

鬼頭 ${ }^{59)}$ は1880年当時の各種主食物から地域パターンを コメ中心型（米食率 $70 \%$ 以上）, コメ・ムギ型（米食率 $70 \%$ 未満, 麦食率 $20 \%$ 未満, 雑穀食率 $20 \%$ 未満), コメ. 雑穀型（米食率 $70 \%$ 未満，麦食率 $20 \%$ 未満，雑穀食率 50 $\%$ 未満)，ムギ卓越型（麦食率 $50 \%$ 以上），雑穀卓越型 (雑穀食率 $50 \%$ 以上), 総合型（米食率30-60\%, 麦食率 20 - 50\% , 雑穀食率 20 - 50\%）に分類している。島根県 および山口県における主食を鬼頭の分類に当てはめて茶 粥習俗がどの主食パターンに属するのかを次に検討した。 島根県においては茶粥習俗が見られなかった出雲市はコ メ中心型であったが，茶粥習俗が多く見られ地域の中で 隠岐の島はコメ・ムギ型であった。隠岐の島以外の地域 は総合型であった。山口県はコメ・ムギ型で隠岐の島, 和歌山県, 奈良県, 大阪府, 京都府と共通している。江 戸時代（?） から隠岐の島や山口県では和歌山県 $40 \sim 42)$, 奈良県 ${ }^{44)}$ と同様にムギだけあるいはコメとムギの混じっ た茶粥を食べていたと思われる。

そこで今回の調査地（島根県・山口県）とこれまでの 調查地 $\left.{ }^{3)}, 16\right)$,17）（和歌山県·奈良県 · 大阪府 · 京都府 滋賀県·三重県·佐賀県）に抢ける現代の茶粥習俗の内 容を比較検討した。

今回の調査において対象者の年齢階層別比率において 山口県では島根県よりも50歳代が占める割合が高く, 70 歳代の占める割合が低かったにもかかわらず山口県は島 根県に比べると茶粥を食べる人の割合が高かった。つま り山口県の茶粥習俗が島根県よりもはるかに根強いこと を示唆している。

本研究では島根県及び山口県の両県において, 茶粥に 使用する茶の中で番茶と回答した者の割合が一番高かっ た。なたブ茶や河原に生育している薬草の一種である カワラケッメイを茶粥に使用していた。大正初期, 島根 県全域で番茶が飲まれていた。また，一部ではカワラケ ツメイ，ハブ茶も飲まれていた24)。このように日常飲ん でいた番茶, カワラケツメイ, ハブ茶を茶粥に利用して きたのであろう。大阪府・京都府では番茶が最も多く用 いられ，カワラケツメイやハブ茶は用いられていなかっ た。このことからカワラケツメイを茶粥に使用すること は島根県及び山口県の特徵であることが明らかとなった。

茶粥を食べる時間帯は島根県と山口県とも朝食で最も 高い割合を示した。朝食に茶粥を食べる習慣は西日本型 食文化であり，北前船の影響を受けているものと思われ る。

著者ら ${ }^{3)}$ は, 茶粥習俗が最も根強い和歌山県ではオカ ユサンがもっとも多く用いられ, 奈良県ではオカイサン とチャガユという呼び名が同程度に用いられ，大阪府 . 京都府 ·滋賀県 · 三重県 ·佐賀県ではチャガユがもっと も多く用いられていたことを明らかにしてきた。また， 島根県ではチャガイがもっとも多く用いられ, 山口県で は大阪府, 京都府, 滋賀県, 三重県, 佐賀県同様にチャ 
ガユという呼び名が最も多かった。茶粥が全県的に食べ られて今なお茶䉼習俗が根強い和歌山県, 奈良県ではチ ヤガユ, チャガイを単にオカイサン，オカユサンという 呼び名も多く用いられていたが，茶粥習俗が全県的でな い地域ではチャガユ，チャガイと呼び，オカイサンとは 区別していたのであろう。このように茶粥習俗の根強さ と呼び名の関連性が島根および山口の両県においても再 確認された。

島根県のツケゴハンの習慣は対象者の約 $20 \%$ 程度であ り，これは茶粥習俗が希薄になってきている京都府，三 重県および佐賀県と同じであった。一方，山口県のツケ ゴハンの習慣は，対象者の約 $50 \%$ であり，これは和歌山 県や奈良県と同じであった。和歌山県, 奈良県同様, 山 口県ではツケゴハンの習慣性が高かったことは茶粥を食 べる習慣性や茶粥の嗜好性の高いことと関係しているの かもしれない。

島根県や山口県の両県では茶粥に入れる具材の頻度は サッマイモ，モチ，アズキが高く，このことは著者らが 調査したすべての地域に共通していた。両県ではサッマ イモの使用頻度が最も高かった。ソラマメを使用してい たことは和歌山県，大阪府および京都府と類似していた。 山口県ではカキモチを茶粥に入れており，このことは奈 良県抢よび大阪府と同じであった。

島根県では「鉄鍋」の使用頻度が最も高く, これは近 畿地方と共通していた。山口県では「羽釜」の使用頻度 が最も高く, 佐賀県と共通していた。茶袋は両県とも使 用頻度は高く, この傾向は和歌山県, 奈良県, 大阪府, 京都府，滋賀県，三重県，佐賀県と同じであった。

茶弱が節米目的で食べられようになったと意識してい る者の割合は島根県，山口県ともに高く，この傾向は和 歌山県, 奈良県, 大阪府, 京都府, 滋賀県, 三重県, 佐 賀県と同じであった。

従って和歌山県, 奈良県, 大阪府, 京都府, 滋賀県, 三重県, 佐賀県における茶粥習俗の内容と今回の調査地 域であった島根県, 山口県に抢ける茶粥習俗の内容には 共通する点が多かった。

本研究では島根県および山口県の茶粥習俗は茶粥を食 べる時間帯, 茶の種類, 茶粥の呼び名, 茶粥に入れる具 の種類で共通点がみられた。歴史的背景21-23)を考察する と, 山口県の茶粥習俗は一部島根県の茶粥習俗から伝わ ったものかもしれない。島根県の茶粥を食べる習慣は隠 岐郡で多く見られたことから島根県の茶粥習俗は北前船 が関与していることが推測された。

今後, 茶粥が盛んに食べられていた地域の周辺地域お よび北前船の寄港地であった日本海側の地域における茶 粥習俗の有無などを明らかにするため, 調査対象地域を さらに拡大し調査を実施することによって，より詳細な 茶粥の分布図を作成し，茶粥の伝播経路や茶粥習俗の定 着・不定着の地域性を明確にする必要がある。

\section{5. 結論}

島根県と山口県において，2003年から2004年にかけて， 50 歳以上の人を対象に茶粥習俗調査を実施し, 次のこと が明らかになった。

（1）島根県と山口県で茶䉼習俗の経験者はそれぞれ約 60 \%と $83 \%$ であり，また両県とも茶粥習俗は広範囲に分 布していた。

(2) 両県とも, 茶粥は「チャガイ」・「チャガユ」という 呼称が最も多く用いられていた。

（3）両県とも茶粥は朝食で最もよく食べられていた。茶 粥に入れた具の中で最も多かったのはサツマイモであ つた。

（4）両県とも, 茶粥は節米目的あるいは健康に良い食べ 物として認識されており，好みに合う料理として継承 されている。

著者らの調査では

島根県と山口県に抢ける茶䉼習俗には共通点が観察さ れた。

両県の茶粥習俗は江戸時代から継承されていることが 示唆された。

\section{文献}

1）山崎あきら：かてもの集, 月明会出版部, p85（1944）

2）久須美祐：日本随筆大成（浪花の風）, 吉川弘文堂, p389 (1977)

3）早川史子 - 前田昭子 - 南幸 - 川井孝子 - 藤沢祥子：京 都 · 大阪 · 三重 ·奈良 · 和歌山の茶粥習俗と分布, 日本食 生活学会誌, 11-3，259-267（2000）

4）瀬川清子 : 食生活の歴史, 東京書房, p19-23（1982）

5）日本食生活全集編集委員会：島根の食事, 農山漁村文化 協会, p288（1991）

6）日本食生活全集編集委員会：山口の食事, 農山漁村文化 協会, p30, p129, p211（1989）

7）日本食生活全集編集委員会：岡山の食事, 農山漁村文化 協会, p45, p89（1985）

8）日本食生活全集編集委員会 : 和歌山の食事, 農山漁村文 化協会, p107, p163（1989）

9）日本食生活全集編集委員会：佐賀の食事, 農山漁村文化 協会, p78, p120, p324（1991）

10）日本食生活全集編集委員会 : 奈良の食事, 農山漁村文化 協会, p221，p223，p276（1992）

11）日本食生活全集編集委員会 : 香川の食事, 農山漁村文化 協会, p284（1990）

12）日本食生活全集編集委員会 : 三重の食事, 農山漁村文化 協会, p129, p184, p228（1987）

13）日本食生活全集編集委員会 : 滋賀の食事, 農山漁村文化 協会, p324（1991）

14）日本食生活全集編集委員会 : 大阪の食事, 農山漁村文化 協会, p233（1991）

15）日本食生活全集編集委員会 : 京都の食事, 農山漁村文化 協会, p105（1985）

16）早川史子 - 日比喜子 : 滋賀の茶粥習俗と分布, 日本食生 活学会誌, 9.52-57 (1988) 
17）早川史子 · 前田昭子 · 水野浄子 · 南幸 - 渋谷里美 : 佐賀 の茶䉼習俗, 日本食生活学会誌, 12-2，176-182（2001）

18) 旭町発行 : 旭町誌 (中), p566-567 (1985)

19）桜江町発行：桜江町誌（下), p440-450（1973）

20）深田喜美恵：明治末期農村の衣食住について, 郷土, 島 根郷土研究会発行, 12号, p33-35（1961）

21）岩国市史編纂委員会編：岩国市史（上），岩国市役所，p 876-881 (1970)

22）田布施町史編纂委員会編：田布施町史，p1241（1990）

23）山口県大島郡東和町編 : 東和町誌別編, 186-191（2004）

24）周東町史編集委員会：周東町史，p283（1979）

25）中国の民俗一島根編一日本民族調査報告書集成，民俗分 布図一朝食の内容，三一書房（1997）

26）隠岐の民俗，島根県教育委員会，p541-489, 報光社 (1973)

$27 ）$ 浜田市発行：浜田市誌（下), p347-348（1973）

28）匹見町発行：石見匹見民俗，p72（1966）

29）西郷町発行 : 西郷町誌 (下), p717 (1976)

30）都万村発行：都万村誌, p1296-1301（1990）

31）六日市町教育委員会発行：六日市町史（二),p851（1988）

32）赤来町発行：赤来町誌, p816（1972）

33）大社町発行：大社町史（下), p40（1995）

34） 温泉津町発行：温泉津町誌（下), p598（1995）

35） 江津市発行 : 江津市誌 (下), p1184（1982）

36）石見町発行：石見町誌（上), p198（1972）

37）川本町教育委員会発行：川本町誌（歴史篇）, p 1268 (1977)

38）大和村教育委員会発行 : 大和村誌 (下), p638（1981）

39） 赤来町：赤来町誌, p816（1974）

40）龍神村誌編さん委員会『龍神村誌 下巻, p327（1987）

41）美山村史編集委員会編：美山村村史，p944（1997）

42）清水町誌編さん委員会, 清水町誌下巻, p731（1998）
43）堀田吉雄 - 岩井宏美 - 橋本鉄男 - 曽根文省 - 中村太郎 · 原泰根 : 近畿の衣と食, 明玄書房, p38（1974）

44）堀田吉雄 - 岩井宏美 - 橋本鉄男 - 曽根文省 - 中村太郎 · 原泰根 : 近畿の衣と食, 明玄書房, p267（1974）

45）上田正子・前田恵子, ふるさとの味をたずねて一隠岐地 方に伝わる手料理 茶がゆ一隠岐郡西郷町農業改良普及所 (1980)

46）日本食生活全集編集委員会 : 山形の食事, 農山漁村文化 協会, p319（1988）

47）新潟県：茶がゆ，新潟県史・資料編23，p283（1988）

48）渋谷歌子 - 本間伸夫 - 石原和夫 - 佐藤恵美子 : 新潟県の 郷土食に関する研究 (第10報), 県立新潟女子短期大学研究 紀要，17，137-145（1980）

49）浜口一夫 : 佐渡の味・食の民俗·茶ガユ, 野島出版, 162 $-163(1979)$

50）本間伸夫：新潟県の食文化の他地域との交流，新潟県生 活文化研究会誌, 1，43-53（1994）

51）都万村発行：都万村誌, p1300（1990）

52）大島町役場：周防大島町誌，p995（1994）

53）松岡利夫：周防長門の生活誌, 山口県教育委員会, 40 (1976)

54）柳川市史編纂委員会編：柳川市史，p436（1988）

55）木村和夫 : 山口県の茶粥についての調査, 瀬戸内海短期 大学紀要19，159-167（1988）

56）淽沢敬三 : 明治文化史, 原書房, 第12巻, p112-113 (1979)

57）早川史子：滋賀の茶粥，滋賀の食事文化 6，1-6（1997）

58）黑崎千晴：主食消費の地域的傾向一明治初期に抢ける米 食率·米麦食率を中心として一, 早稲田大学高等学院研究 年誌12, p17 (1967)

59）鬼頭宏 : 明治前期の主食構成とその地域パターン, 上智 経済論集，30-43（1986） 